\title{
Treatment of soybean seeds with molybdenum and inoculant: nitrate reductase activity and agronomic performance
}

\author{
Ewerton Gewehr'*, Otávio de Oliveira Corrêa', Anna dos Santos Suñé', Gabriel Bandeira Duarte', \\ Luciano do Amarante', Lilian Vanussa Madruga de Tunes', Daniele Brandstetter Rodrigues'
}

'Federal University of Pelotas, Pelotas, Brazil

*Corresponding author, e-mail: ewertongewehr@hotmail.com

\begin{abstract}
The aim of this study was to analyze the effects of molybdenum and inoculant application via seed treatment in soybean, and their role in the nitrate reductase enzyme activity, agronomic traits and physiological quality of the produced seeds. The experiment was conducted at the Federal University of Pelotas (UFPel), Rio Grande do Sul state, Brazil. The treatments were shaped by five doses of molybdenum (zero; $16 ; 32 ; 48 ; 64 \mathrm{~g} .100 \mathrm{~kg}^{-1}$ of seeds) combined with the presence and absence of liquid inoculant (Bradyrhizobium japonicum), at a dose of 200 $\mathrm{mL}$ per $100 \mathrm{~kg}$ of seeds. The evaluations of nitrate reductase activity, agronomic traits and physiological seed quality were performed in the present work. The measured agronomic traits were: plant height, number of pods per plant, number of seed per plant and thousand-seed weight. Standard germination test was executed to evaluate the produced seed viability. First germination counting, accelerated aging test, cold test, plantlet shoot and root length, plantlet shoot and root dry mass, and field seedling emergence were utilized to measure the seed vigour. Molybdenum, both in presence and absence of inoculant, positively influenced the enzymatic activity, for both vegetative and reproductive stages. The addition of inoculant and molybdenum provided increase in the vigour of the produced seeds. The enzyme activity was positively correlated with the agronomic traits and vigour tests. The addition of inoculant and molybdenum in the seed treatment provides a better expression of nitrate reductase activity and vigour of the produced seeds.
\end{abstract}

Keywords: Glycine Max L., sodium molybdate, Bradyrhizobium japonicum, enzymatic activity, seed quality

\section{Introduction}

The soybean crop (Glycine Max L.) holds a great social and economic value, being considered one of the crops with highest world importance, participating in animal and human feeding, being a source of proteins, lipids (soybean oil), minerals and carbohydrates. In this manner, the use of technologies for yield increase is indispensable, and the seed treatment technique has contributed for the sustainability of the current production system.

Among the advantages attributed to seed treatment are: operational easiness, higher efficiency of the fertilizer use, elevated uniformity of elements distribution, higher availability of nutrients in the initial stage of plant growth, among others (Faroog et al., 2012). This fact contributes to increase seed development and the growth and development of the plantlets.

The addition of inoculants in the soybean crop becomes increasingly necessary, since the bacteria of the Bradyrhizobium genus present an important function in the nitrogen cycle. The bacteria associate to the root system and stablish an important symbiosis, from which it supplies the nitrogen that the plant requires, through specialized root structures (nodules), within which occurs the process of biological nitrogen fixation (Moraes, et al., 2008).

During the processes of infection and Received: 02 May 2017 Accepted: 21 December 2018 
nodule development, which are perfectly interlinked to the plants through xylem and phloem vessels, the required energy for cell divisions is obtained from the oxidation of the carbohydrates produced in the shoot part of the host plant (Silveira et al. 2011). However, in order for the process to be efficient, it is necessary that the plants are in a good nutritional situation, both with macro and micronutrients.

Among the micronutrients, the molybdenum (Mo) presents a great importance to the plant, since its function is related to the biological nitrogen fixation, acting as a co-factor of the nitrate reductase enzyme, which acts in the reduction of the nitrate to ammonium, in the plant (Araújo et al. 2008).

Therefore, the biological nitrogen fixation and the nitrate reductase enzyme activity, are fundamental for the incorporation of the inorganic nitrogen into complex organic molecules. Consequently, these events constitute an important assistance in the obtainment of significant gains in production, and in the physiological quality of the produced seeds.

In this manner, the application of the inoculant along with the molybdenum increases the nitrate reductase activity, and improves the agronomic traits and the physiological quality of the produced seeds. In view of the foregoing, the aim of this work was to analyze the application effects of the inoculant and molybdenum via treatment of soybean seeds, and its function in nitrate reductase enzyme activity, agronomic traits and physiological quality of the produced seeds.

\section{Material and Methods}

The experiment was performed in an experimental area, in the Laboratory of Seeds Analysis and in the Laboratory of Biochemistry, both belonging to the Federal University of Pelotas (UFPEL), municipality of Capão do Leão, Rio Grande do Sul state, Brazil. The treatments consisted of five doses of molybdenum (Mo), utilizing as source the Sodium Molybdate $\left(\mathrm{Na}_{2} \mathrm{MOO}_{4}\right.$ ) (solution 127g. $\left.\mathrm{L}^{-1}\right)$. The corresponding doses were: zero; 16; 32; 48; 64 g.100 $\mathrm{kg}^{-1}$ of seeds, combined with the presence and absence of the liquid inoculant, in the dosage of $200 \mathrm{ml}$ per 100 $\mathrm{kg}$ of seeds, containing Bradyrhizobium japonica bacteria, in the concentration of $5 \times 109 \mathrm{Cfu} / \mathrm{Ml}$, via treatment of soybean seeds.

The seeds were treated with the doses of the sodium molybdate and the Sepiret ${ }^{\circledR}$ polymer, utilizing $400 \mathrm{~mL}$. $100 \mathrm{~kg}$ of seeds ${ }^{-1}$. The spray volume utilized was $800 \mathrm{~mL}$. $100 \mathrm{~kg}$ of seeds ${ }^{-1}$, completed with water. The overlay was performed by applying the doses of the products over four replicates of $200 \mathrm{~g}$ of seeds per treatment. The products were applied directly at the bottom of the plastic bag, and spread up to a height of approximately $15 \mathrm{~cm}$. Afterwards, the seeds were placed inside the same plastic bags and agitated for $3 \mathrm{~min}$, until total distribution of the spray mix over the seed surface. Subsequently, the seeds were placed for drying at ambient temperature for 24 hours. In occasion of the sowing, the inoculant was added over the $200 \mathrm{~g}$ of already treated seeds, and the plastic bags were agitated until total distribution of the inoculant.

The sowing was performed in 20-liter vases, filed with sieved forest soil.The fertilizations were performed according with the data of the soil analysis (ROLAS, 2004). 10 seeds were sowed per vase, and after emergence, only 4 plants per vase were allowed, through thinning. The irrigation and phytosanitary management were performed according to the necessity of the crop.

During the the experiment, leaf collections were performed in different phenological stages for the evaluation of the enzymatic activity. The remaining plants were conducted until the stage of field physiological maturity (R8), with later performing of the evaluation of the agronomic traits and physiological quality of the produced seeds.

In order to determine the nitrate reductase enzyme activity, leaves were collected from four replicates per treatment, out of the last trifoliate developed in the vegetative (V3) and reproductive (R5) stages. From each sample, 4 sub-samples were made, consisting of approximately $1 \mathrm{~g}$. The samples were macerated with $100 \mathrm{~mL}$ of liquid nitrogen $\left(\mathrm{N}_{2}\right)$ and $4 \mathrm{ml}$ of extraction buffer (Hepes- $\mathrm{KOH}, 50$ $\mathrm{mM}(\mathrm{pH} 7,6)$, containing 5 mM EDTA, 10 MM FAD, 
$3 \%(\mathrm{~W} / \mathrm{V})$ casein and $1 \mathrm{mM}$ (DTT). Afterwards, the substrates were placed in Eppendorf tubes and centrifuged at 13,200 rpm for 10 minutes at a temperature of $4^{\circ} \mathrm{C}$. Afterwards, the protein purification was performed in PD10 columns (Amersham Biosciences - Sephadex G25) previously balanced with the essay buffer (Hepes-KOH, $50 \mathrm{mM}(\mathrm{pH} 7,6)$, containing $5 \mathrm{mM}$ EDTA, $10 \mu \mathrm{M}$ FAD and $1 \mathrm{mM}$ DTT). Immediately, in the fraction of the purified protein, the essay buffer was added, NADH $0.1 \mathrm{mM}$ and $\mathrm{KNO}_{3}$ $0.2 \mathrm{mM}$, totalizing a volume of $1 \mathrm{~mL}$, being deposited in Eppendorf tubes and incubated in water bath at a temperature of $30^{\circ} \mathrm{C}$ for $30 \mathrm{~min}$. After this period, the reaction was paralyzed with $125 \mu \mathrm{L}$ of zing acetate $500 \mathrm{mM}$. The mixture was centrifuged at 13,200 rpm during $4 \mathrm{~min}$ at $4^{\circ} \mathrm{C}$, and the supernatant was utilized for determining the amount of nitrite produced, according to the methodology of Hageman \& Reed (1980). For the determination were added $1 \mathrm{~mL}$ of distilled water, $1 \mathrm{~mL}$ of sulfanilamide $1 \%(\mathrm{P} / \mathrm{V})$ in $\mathrm{HCl} 1,5 \mathrm{~N}$ and $1 \mathrm{~mL}$ of $\mathrm{N}$ (naphthyl)- ethylenediamine $2 \mathrm{HCl}$ $0,02 \%(P / V)$ (for the making of the blank sample, the supernatant containing nitrite was replaced by distilled water). The mixture kept reacting for $30 \mathrm{~min}$, and the reading was performed through a spectrophotometer at $540 \mathrm{~nm}$, against the blank sample. After the reading, the data were placed in the equation of the calibration curve and adjusted to one unit of nmol of $\mathrm{NO}_{2} \cdot \mathrm{gmf}^{-1} \cdot \mathrm{h}^{-1}$.

For the evaluation of the agronomic traits, 3 plants were collected per replicate, totalizing 12 plants per treatment, and were measured the height of the plants, counting of the number of legumes per plant and number of seeds per plant. After the threshing, the water content of the seeds was determined, and homogenized in $13 \%$ of humidity. Eight samples of 100 seeds were collected in order to determine the thousand-seed weight.

For the determination of the physiological quality of the produced seeds, the following tests were evaluated:

Germination test (G): performed with four sub-samples of 50 seeds, sowed in moistened Germites ${ }^{\oplus}$ paper rolls with distilled water in the proportion of 2.5 times the weight of the paper. The rolls were placed into the germinator at a temperature of $25^{\circ} \mathrm{C}$. The germination was accomplished at 8 days, in which the percentage of normal plantlets was determined, according with the Rules for Seed Testing (Brasil, 2009).

First germination count (FGC): was performed along with the germination test, with the counting being performed in the fifth day after sowing (Brasil, 2009).

Accelerated aging test (AA): for the determination of the test the methodology of Marcos Filho (2005) was adopted, using Gerbox ${ }^{\oplus}$ containers with $40 \mathrm{~mL}$ of water at the bottom, with an aluminum screen fixed in the interior of the container, being the seeds distributed in a uniform manner over the screen. Afterwards, the containers were closed and placed inside $a$ BOD incubator, with a controlled temperature of $41^{\circ} \mathrm{C}$ for 48 hours. After this period the seeds were put to germinate, according to the methodology, in the test of the first germination count (Brasil, 2009).

Cold test (CT): performed with four subsamplings of 50 seeds, following the methodology of the germination test. The rolls were placed in refrigerator at the temperature range from 8 to $10^{\circ} \mathrm{C}$, during 7 days, after that, they were kept in the germinator at the temperature of $25^{\circ} \mathrm{C}$, and the counting of the normal plantlets was performed in the fifth day.

Length of shoot (SL) and root (RL) parts: performed with four sub-samples of 20 seeds. The seeds were put to germinate, aligned in the upper part of the Germitest ${ }^{\circledast}$ paper moistened at 2.5 times its weight. Afterwards, the rolls were placed in a germinator at $25^{\circ} \mathrm{C}$. The length was evaluated at 5 days, with the aid of a graduated ruler, by separately measuring the shoot and root lengths of 10 randomly selected normal plantlets. The average shoot and root lengths were determined by the sum of each replicate measures and by dividing it by the number of evaluated plants, in accordance with the methodology described by Nakagawa (1999).

Dry mass of shoot (SDM) and root (RDM) parts: were utilized the shoot and root parts originated from the test of plantlets height, afterwards, they were placed in a drying oven at $70^{\circ} \mathrm{C}$ with forced air circulation, during $48 \mathrm{~h}$. Afterwards, the samples were weighed in 
analytical balance with precision of $0,0001 \mathrm{~g}$. The results were expressed in mg.plantlet ${ }^{-1}$.

Field emergence of plantlets (FE): performed with 200 seeds per treatment, divided into four replicates of 50 seeds, distributed in grooves of 1-meter length and $3 \mathrm{~cm}$ depth, with $2 \mathrm{~cm}$ within seeds and spaced $20 \mathrm{~cm}$ within lines. The counting was performed at 14 days after sowing, observing the emerged plantlets, only considering those which emitted the cotyledons over the surface of the soil.

Statistical analysis: performed with the set of information obtained through the synthesis of the field and laboratory data. The Analysis of Variance was performed at $5 \%$ probability with the purpose of identifying the interaction between the use of the inoculant $x$ molybdenum doses. When significant, the interaction was dismembered into the simple effects for the qualitative factor use of the inoculant. For the effect of the quantitative factor (molybdenum dosage), linear regression was employed, with adjustment of highest polynomial degree through the T test at $5 \%$ probability. These effects were respective for every level of the qualitative factor. With the aim of identifying the association tendency within the measured variables, a linear correction was performed, with significance based in the T test at $1 \%$ and $5 \%$ probability. The statistical software utilized was the Winstat 1.0 (Machado \& Conceição, 2003).

\section{Results and Discussions}

The analysis of variance revealed interaction between the use of inoculant $x$ molybdenum doses for the variables of nitrate reductase enzyme activity obtained in the vegetative stage (V3), and the nitrate reductase enzyme activity obtained in the reproductive stage (R5) of plants originated from seeds treated with different molybdenum doses with presence and absence of inoculant, at $5 \%$ probability; however, for the variables: plant height, thousand-seed weight, shoot dry mass and root dry mass, there was no significant variation.

The results of the nitrate reductase enzyme activity in the collected leaves in the vegetative (V3) and reproductive (R5) stages, originated from the plants that received the inoculant via seed, on sowing, presented a similar performance, evidencing the higher enzymatic activity in the doses of zero (witness); 16; 32 and $48 \mathrm{~g}$ of $M 0.100 \mathrm{~kg}^{-1}$ of seeds when associated to the inoculants. As for the dosage of $64 \mathrm{~g}$. of Mo.100 $\mathrm{kg}^{-1}$ of seed, no statistical difference was verified within the plants that did receive and those that did not receive inoculants via seed

Table 1. Nitrate reductase enzyme activity obtained in the vegetative V3 (NRA V3) and reproductive R5 (NRA R5) stages of plants originated from seeds treated with different molybdenum doses, with presence and absence of the inoculant. UFPel, 2015.

\begin{tabular}{ccccccc}
\hline \multirow{2}{*}{ Variable } & \multirow{2}{*}{ Inoculant } & \multicolumn{5}{c}{ Dosage (sodium molybdate $\left(\right.$ solution 127g. $\mathrm{L}^{-1}$ )) } \\
\cline { 3 - 6 } & & 0 & 16 & 32 & 48 & 64 \\
\hline \multirow{3}{*}{ NRA V3 } & Presence & $7,03 \mathrm{~A}$ & $28,62 \mathrm{~A}$ & $33,83 \mathrm{~A}$ & $28,69 \mathrm{~A}$ & $26,56 \mathrm{~A}$ \\
& Absence & $4,50 \mathrm{~B}$ & $5,01 \mathrm{~B}$ & $5,14 \mathrm{~B}$ & $10,39 \mathrm{~B}$ & $28,72 \mathrm{~A}$ \\
& $\mathrm{CV}(\%)$ & 9,25 & & & & \\
\hline \multirow{3}{*}{ NRA R5 } & Presence & $50,33 \mathrm{~A}$ & $55,72 \mathrm{~A}$ & $62,22 \mathrm{~A}$ & $60,72 \mathrm{~A}$ & $58,06 \mathrm{~A}$ \\
& Absence & $21,02 \mathrm{~B}$ & $21,02 \mathrm{~B}$ & $26,00 \mathrm{~B}$ & $49,55 \mathrm{~B}$ & $57,70 \mathrm{~A}$ \\
\cline { 2 - 6 } & $\mathrm{CV}(\%)$ & 6,47 & & & & \\
\hline Same letters on the column do not significantly differ within each other at the level of 5\% error probability by Tukey's grouping model (*significant at the level of 5\%
\end{tabular}
error probability by the $\mathrm{F}$ test; $\mathrm{NS}=$ not significant).

treatment in the occasion of sowing (Table 1).

When observing the effect of the molybdenum doses, it was verified that the activity of the nitrate reductase in the $\mathrm{V} 3$ stage, with the presence of the inoculant, framed into a quadratic polynomial model, and the dosage which provided higher enzyme activity was 39,65

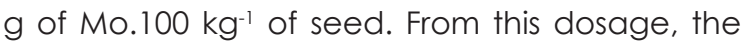
enzyme activity presented reduction. However, in the absence of the inoculant, the molybdenum doses provided increase in the enzymatic activity of about $84 \%$ in relation to the witness, and the dosage of $64 \mathrm{~g}$ of $\mathrm{Mo} .100 \mathrm{~kg}^{-1}$ of seed provided higher enzymatic activity (Figure 1A).

As for the enzymatic activity of the leaves collected in the reproductive stage (R5), it was verified that in the presence of the inoculant, the molybdenum dosage that presented the 
highest participation in the enzyme activity was that of $41,64 \mathrm{~g}$ of $M 0.100 \mathrm{~kg}^{-1}$ of seeds, with a slight reduction from this dosage. Concerning the response of the molybdenum doses in the absence of the inoculant, an increase was verified in the nitrate reductase enzyme activity as the molybdenum dosage increased, a fact evidenced by the enzymatic activity of 57,70 $\mathrm{nmol} \mathrm{NO} \cdot \mathrm{gmf}^{-1} \cdot \mathrm{h}^{-1}$ in the dosage of $64 \mathrm{~g}$ of $\mathrm{Mo}$.
$100 \mathrm{~kg}^{-1}$ of seed, cooperating with $63 \%$ in relation to the witness $\left(21,02 \mathrm{nmol} \mathrm{NO}_{2}^{-} \cdot \mathrm{gmf}^{-1} \cdot \mathrm{h}^{-1}\right)$ (Figure 1B).

The results resemble those by Donato et al. (2004), in which it is reported that nitrogenfixing bacteria positively influence the activity of enzymes. And Toledo et al. (2010) reported that the nitrate reductase enzyme activity is affected by the fertilization with molybdenum, being
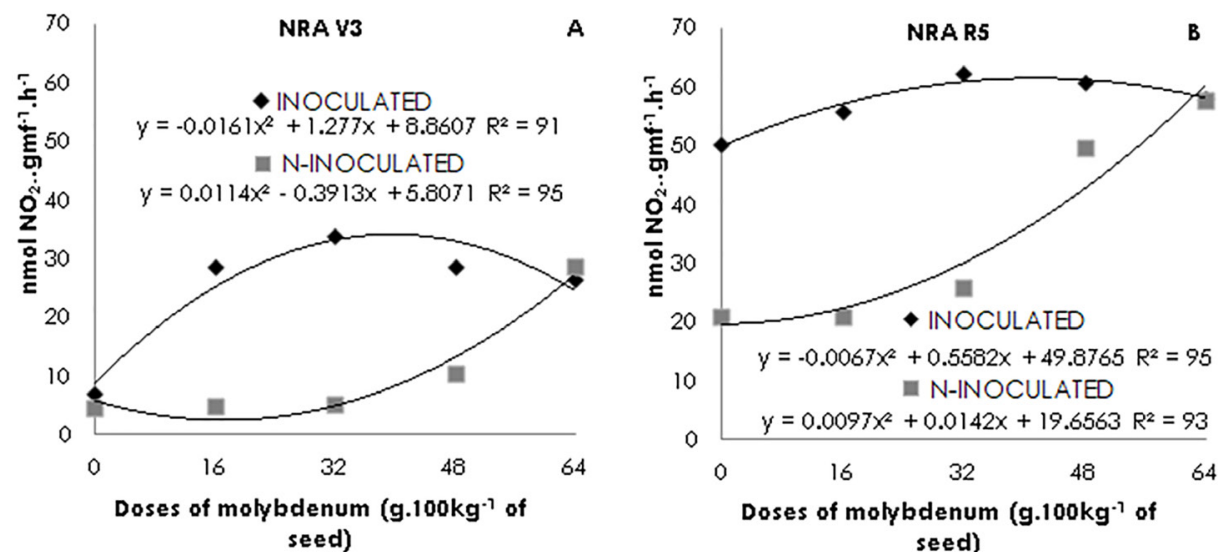

Figure 1. (A) - Nitrate reductase enzyme activity obtained in the vegetative stage (V3); (B) - Nitrate reductase enzyme activity obtained in the reproductive stage (R5) of plants originated from seeds treated with different doses of molybdenum, with presence and absence of the inoculant. UFPel, 2015.

higher in the presence of the micronutrient.

In order for the nitrogen assimilation to be possible, it is necessary that the nitrate be first reduced to nitrite and then to ammonium (Chaiklahan et al., 2010). In the first stage of the nitrogen assimilation, the nitrate is reduced to nitrite in the cytosol by the nitrate reductase enzyme. (Fernandez \& Galvan, 2008).

According to Reis et al. (2007), the nitrate reductase enzyme activity is induced by its substrate, being considered a key-enzyme in the regulation of the nitrogen availability for the plants. This fact allowed an increase in the activity of the nitrate reductase by the plants evaluated in the experiment, since that with the presence of the inoculant there was a higher biological nitrogen fixation by the Bradyrhizobium bacteria, and a higher amount of substrate for the enzyme. Altogether, the molybdenum aided in the increase of the enzyme activity, since it participates as a co-factor of this enzyme.

The plants originated from the seed that received addition of inoculant in the occasion of sowing presented a superior performance concerning plant height, number of pods per plant and number of seeds per plant. Furthermore, these same plants produced seeds with higher thousand-weight (Table 2).

It is possible to affirm, hence, that the presence of the Bradyrhizobium bacteria provided a higher fixation of atmospheric nitrogen, thus promoting a higher plant height, number of pods and seeds per plant and thousand-seed weight.

In the same manner, Bahry et al. (2014) verified that the nitrogen applied in the reproductive stage of the soybean increased the number of grains per pod, and the thousand-seed weight. Similarly, studies performed by Golo et al. (2009), demonstrated that for the agronomic traits: number of pods per plants and number of seeds per plant, the treatment with the inoculant was superior in relation to the treatment without the inoculant.

As to the molybdenum doses, a linear tendency was verified for the variables: plant height and thousand-seed weight (Figure 2A and 2B). Hence, each gram of Sodium Molybdate added to seeds provided an increment of 0,08 $\mathrm{cm}$ in the height of the plants and of 0,39 in the 
thousand-seed weight. It is worth noting that the highest molybdenum dosage provided an increase of approximately $10 \%$ for plant height and $13 \%$ for the thousand-seed weight, when compared with the witness.

Table 2. Agronomic traits: plant height (PH); number of pods per plant (NPP); number of seeds per plant (NSP); of plants subjected to molybdenum doses and presence and absence of inoculant via seed treatment on sowing. UFPel, 2015.

\begin{tabular}{|c|c|c|c|c|c|c|c|}
\hline \multirow{2}{*}{ Variable } & \multirow{2}{*}{ Inoculant } & \multicolumn{5}{|c|}{ Dosage (sodium molybdate (solution 127g..-1)) } & \multirow{2}{*}{ Mean } \\
\hline & & 0 & 16 & 32 & 48 & 64 & \\
\hline \multirow{4}{*}{$\mathrm{PH}(\mathrm{cm})$} & Presence & 58,83 & 60,96 & 61,44 & 62,20 & 63,00 & $61,29^{a}$ \\
\hline & Absence & 54,17 & 57,42 & 59,50 & 60,85 & 61,38 & $58,66 \mathrm{~B}$ \\
\hline & Mean & $56,50^{*}$ & 59,19 & 60,47 & 61,52 & 62,19 & \\
\hline & $\mathrm{CV}(\%)$ & 3,52 & & & & & \\
\hline \multirow{4}{*}{ NPP (n) } & Presence & 54 & 54 & 56 & 56 & 58 & $55^{a}$ \\
\hline & Absence & 48 & 49 & 49 & 52 & 53 & $50 B$ \\
\hline & Mean & $51^{\mathrm{NS}}$ & 52 & 53 & 54 & 55 & \\
\hline & CV(\%) & 5,83 & & & & & \\
\hline \multirow{4}{*}{ NSP (n) } & Presence & 104 & 118 & 107 & 114 & 112 & $111^{a}$ \\
\hline & Absence & 92 & 95 & 103 & 113 & 106 & $102 B$ \\
\hline & Mean & $98^{\mathrm{NS}}$ & 106 & 105 & 114 & 109 & \\
\hline & $\mathrm{CV}(\%)$ & 13,18 & & & & & \\
\hline \multirow{4}{*}{ WTS (g) } & Presence & 193,50 & 204,00 & 214,04 & 216,61 & 221,73 & $209,98^{a}$ \\
\hline & Absence & 174,83 & 177,12 & 183,77 & 193,40 & 194,89 & $184,80 \mathrm{~B}$ \\
\hline & Mean & $184,16^{*}$ & 190,56 & 198,91 & 205,01 & 208,31 & \\
\hline & CV(\%) & 2,93 & & & & & \\
\hline
\end{tabular}

The results are in accordance with the results found by Milani et al. (2008), who observed that the content of molybdenum within the seed positively influenced the height in plants. Furthermore, Golo et al. (2009) reported that the molybdenum plus cobalt presented a significant

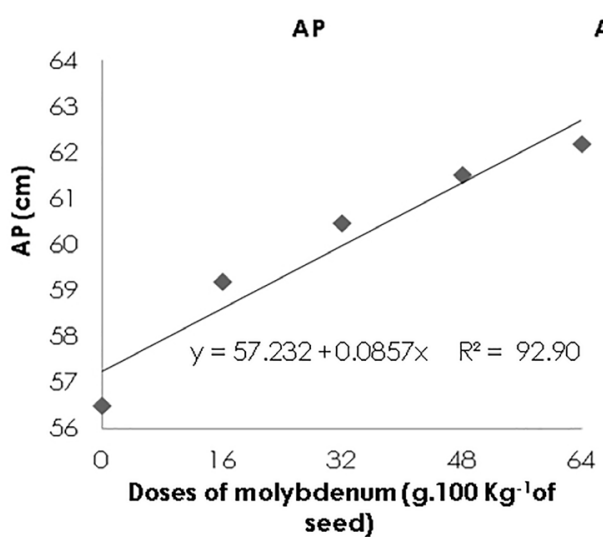

Figure 2. Agronomic traits: $(\mathrm{A})$ - plant height $(\mathrm{PH})$; subjected to different molybdenum doses via seed treatment; (B) - thousand-seed weight (TSW) originated from plants treated with different molybdenum doses before sowing. UFPel, 2015.

Concerning the physiological quality of the seeds, the variables: first germination count, germination, cold test and field emergence did not present significant difference for the treatments. As for the accelerated aging test, it was verified that the produced seeds originated from plants which received inoculant in occasion of the sowing presented a better performance, result for the thousand-seed weight. This increment might be explained by the participation of the molybdenum in the treatments, since it assists the nitrate reductase enzyme, being its co-factor, and allowing a higher incorporation of nitrogen by the plants.

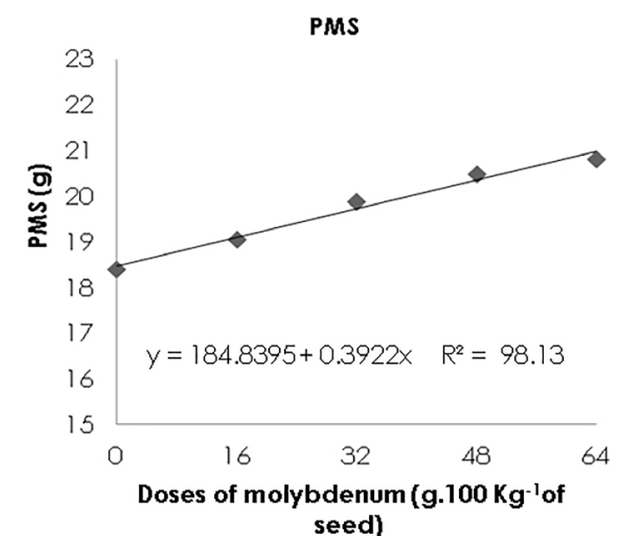

comparing to those which did not receive the inoculant. However, no significant effect was observed within the molybdenum doses (Table 3).

Similar results were obtained by Cassán et al. (2009), with maize and soybean crops, in which the seed treatment with inoculant promoted significant increases in seed vigour. 
Table 3. Physiological quality of soybean seed produced: first germination count (FGC); germination (G); cold test $(\mathrm{CT})$; accelerated aging ( $\mathrm{AE})$; field emergence (FE); of plants subjected to doses of molybdenum and presence and absence of inoculant via seed treatment during sowing. UFPel, 2015.

\begin{tabular}{|c|c|c|c|c|c|c|c|}
\hline \multirow{2}{*}{ Variable } & \multirow{2}{*}{ Inoculant } & \multicolumn{5}{|c|}{ Dosage (sodium molybdate (solution 127g. $\mathrm{L}^{-1}$ )) } & \multirow{2}{*}{ Mean } \\
\hline & & 0 & 16 & 32 & 48 & 64 & \\
\hline \multirow{4}{*}{ FGC (\%) } & Presence & 92 & 93 & 94 & 94 & 94 & $93^{\mathrm{NS}}$ \\
\hline & Absence & 93 & 93 & 91 & 90 & 91 & 92 \\
\hline & Mean & $92^{\mathrm{NS}}$ & 93 & 93 & 92 & 92 & \\
\hline & $\mathrm{CV}(\%)$ & 3,46 & & & & & \\
\hline \multirow{4}{*}{$G(\%)$} & Presence & 97 & 99 & 98 & 99 & 99 & $98^{\mathrm{NS}}$ \\
\hline & Absence & 98 & 99 & 96 & 98 & 96 & 97 \\
\hline & Mean & $98^{\mathrm{NS}}$ & 99 & 97 & 99 & 97 & \\
\hline & $\mathrm{CV}(\%)$ & 1,35 & & & & & \\
\hline \multirow{4}{*}{ СТ (\%) } & Presence & 97 & 97 & 98 & 98 & 98 & $97^{\mathrm{NS}}$ \\
\hline & Absence & 96 & 98 & 96 & 98 & 98 & 97 \\
\hline & Mean & $96^{\mathrm{NS}}$ & 97 & 97 & 98 & 98 & \\
\hline & $\mathrm{CV}(\%)$ & 1,54 & & & & & \\
\hline \multirow{4}{*}{$\mathrm{AA}(\%)$} & Presence & 95 & 96 & 94 & 96 & 93 & $95^{\mathrm{NS}}$ \\
\hline & Absence & 91 & 98 & 93 & 96 & 94 & 94 \\
\hline & Mean & $93^{\mathrm{NS}}$ & 97 & 94 & 96 & 94 & \\
\hline & $\mathrm{CV}(\%)$ & 5,08 & & & & & \\
\hline \multirow{4}{*}{ FE (\%) } & Presence & 91 & 94 & 93 & 94 & 92 & $93^{a}$ \\
\hline & Absence & 85 & 90 & 92 & 87 & 90 & $89 B$ \\
\hline & Mean & $88^{\text {NS }}$ & 92 & 92 & 91 & 91 & \\
\hline & CV(\%) & 3,89 & & & & & \\
\hline
\end{tabular}

Same letters on the column do not statistically differ within each other at the level of $5 \%$ error probability by Tukey's grouping model (*significant at the level of $5 \%$ error probability by the $\mathrm{F}$ test; $\mathrm{NS}=$ not significant).

Concerning the molybdenum doses, similar results were found by Possenti \& Villela (2010), who, for the germination variable, did not evidence a significant difference in the molybdenum-enrichment of the seeds. Furthermore, in studies performed by Milani et al. (2010) with molybdenum fertilization in the podwere observed in the physiological quality of the seeds.

As for the variables: shoot and root lengths of the plantlets originated from the seeds produced by plants that received the inoculant during the seed treatment, their values were superior to those that did not filling stage of soybean, no significant effects receive the inoculant, pointing to an increase of

Table 4. Physiological quality of the soybean seeds produced: shoot length (SL); root length (RL); shoot dry mass (SDM); root dry mass (RDM); of plants subjected to molybdenum doses and presence or absence of inoculant via seed treatment on sowing. UFPel, 2015.

\begin{tabular}{|c|c|c|c|c|c|c|c|}
\hline \multirow{2}{*}{ Variable } & \multirow{2}{*}{ Inoculant } & \multicolumn{5}{|c|}{ Dosage (sodium molybdate (solution 127g..-1)) } & \multirow{2}{*}{ Mean } \\
\hline & & 0 & 16 & 32 & 48 & 64 & \\
\hline \multirow{4}{*}{$\mathrm{SL}(\mathrm{cm})$} & Presence & 15,46 & 14,90 & 16,50 & 15,44 & 16,49 & $15,76^{a}$ \\
\hline & Absence & 15,24 & 14,13 & 13,93 & 13,75 & 14,15 & $14,24 \mathrm{~B}$ \\
\hline & Mean & $15,35^{\mathrm{NS}}$ & 14,51 & 15,21 & 14,59 & 15,32 & \\
\hline & CV (\%) & 10,25 & & & & & \\
\hline \multirow{4}{*}{$\mathrm{RL}(\mathrm{cm})$} & Presence & 23,33 & 23,70 & 24,12 & 23,18 & 22,78 & $23,42^{a}$ \\
\hline & Absence & 23,20 & 21,79 & 22,21 & 21,85 & 22,05 & $22,28 \mathrm{~B}$ \\
\hline & Mean & $23,27^{\mathrm{NS}}$ & 22,74 & 23,16 & 22,52 & 22,42 & \\
\hline & CV (\%) & 4,02 & & & & & \\
\hline \multirow{4}{*}{$\mathrm{SDM}$ (mg) } & Presence & 134,42 & 134,93 & 148,05 & 148,98 & 147,82 & $142,84^{a}$ \\
\hline & Absence & 111,04 & 120,72 & 123,39 & 139,61 & 141,71 & $127,29 \mathrm{~B}$ \\
\hline & Mean & $122,73^{*}$ & 127,82 & 135,72 & 144,29 & 144,76 & $22,38^{a}$ \\
\hline & CV (\%) & 7,97 & & & & & \\
\hline \multirow{4}{*}{ RDM (mg) } & Presence & 20,38 & 21,78 & 23,99 & 22,69 & 23,08 & \\
\hline & Absence & 18,45 & 20,32 & 20,31 & 22,67 & 22,42 & $20,83 \mathrm{~B}$ \\
\hline & Mean & $19,41^{*}$ & 21,05 & 22,15 & 22,68 & 22,75 & \\
\hline & CV (\%) & 7,81 & & & & & \\
\hline
\end{tabular}

Same letters on the column do not statistically differ within each other at $5 \%$ of error probability by Tukey's grouping model (*significant at the level of $5 \%$ error probability by the F test; NS = not significant). 
approximately $10 \%$ in the shoot length and $5 \%$ in the root length, in the presence of the bacteria. It might be observed, though, that the shoot and root lengths were not influenced by the different utilized doses of molybdenum (Table 4).

Still in table 4, an expressive increase in shoot and root dry mass might be verified, thus affirming a better vigour in the produced seeds originated from plants that received the inoculant during sowing.

Similar results were found by Rampim et al. (2012), who observed increase in the shoot and root length due to wheat seed-treatment with Azospirillum brasilense, demonstrating a positive interference of the bacteria in initial development of the plantlets.

According with figure $3 \mathrm{~A}$ and $3 \mathrm{~B}$, it might be observed that the different molybdenum doses positively influenced the shoot dry mass and the root dry mass, showing a linear increase in the gain of dry phytomass for both analyzed variables. It is worth noting that for each gram of sodium molybdate (solution $127 \mathrm{~g} \cdot \mathrm{L}^{-1}$ ) added to the seeds, an increment of 0,378 and 0,0519 milligrams was observed for shoot and root dry phytomass, respectively, in accordance with Oliveira et al. (2010), who verified that the molybdenum applied in castor bean presented a positive influence over the dry mass production of the plants.
MSPA

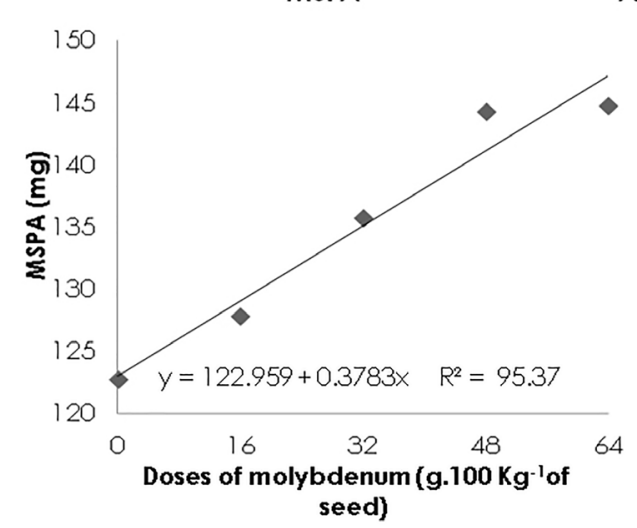

A

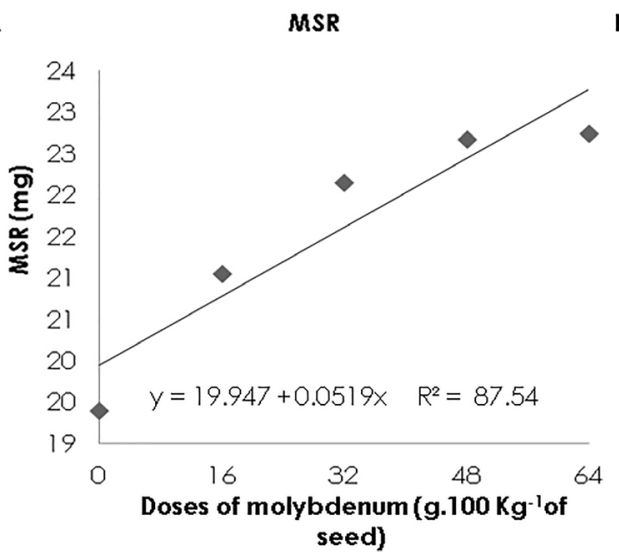

Figure 3. (A) - Shoot dry mass SDM; (B) - Root dry mass RDM; of plants subjected to different molybdenum doses via seed treatment before sowing. UFPel, 2015.

In the analysis of the obtained correlation coefficients between the tests of physiological quality of soybean seeds produced and the nitrate reductase enzyme activity in the stages V3 and R5, it could be verified that the enzymatic activity correlated positively with the variables of accelerated aging and shoot and root dry mass (Table 5), pointing that the higher is the activity of the enzyme, the higher is the increase in shoot and root dry mass and higher the vigour of the seeds.

In accordance with the data presented in Table 6, the correlation of the enzymatic activity obtained in the vegetative (V3) and reproductive (R5) stages with the agronomic traits was significant and positive for the

Table 5. Linear correlation between the variables related to the nitrate reductase enzyme activity and the physiological quality of the seeds produced. UFPel, 2015.

\begin{tabular}{ccc}
\hline & NRA V3 & NRA R5 \\
\hline FGC & $0,20^{\text {NS }}$ & $0,01^{\text {NS }}$ \\
G & $0,13^{\text {NS }}$ & $0,03^{\text {NS }}$ \\
CT & $0,21^{\text {NS }}$ & $0,14^{\text {NS }}$ \\
AA & $0,43^{*}$ & $0,38^{*}$ \\
FE & $0,04^{\text {NS }}$ & $0,07^{\text {NS }}$ \\
SL & $0,25^{\text {NS }}$ & $0,25^{\text {NS }}$ \\
RL & $0,29^{\text {NS }}$ & $0,24^{\text {NS }}$ \\
SDM & $0,65^{*}$ & $0,76^{*}$ \\
RDM & $0,60^{*}$ & $0,63^{*}$ \\
\hline
\end{tabular}

**Significant by the $t$ test at the level of $1 \%$ error probability; * Significant by the $t$ test at $5 \%$ error probability; $N S=$ not significant by the $t$ test. First germination count (FGC); germination (G); cold test (CT); accelerated aging (AA); field emergence (FE); shoot length (SL); root length (RL); shoot dry mass (SDM); root dry mass (RDM): nitrate reductase enzyme activity obtained in the vegetative stage $V 3$ (NRA V3) and nitrate reductase enzyme activity obtained in the reproductive stage R5 (NRA R5). 
variables: thousand-seed weight, plant height, number of pods per plant and number of seeds per plant. Furthermore, it was observed that the highest obtained correlation was with the nitrate reductase enzyme activity and the variable thousand-seed weight, with a correlation of $r=$ 0,81 in the vegetative stage and $r=0,83$, in the reproductive stage.

Table 6. Linear correlation between the variables related to the nitrate reductase enzyme activity and the soybean agronomical traits. UFPel, 2015.

\begin{tabular}{ccc}
\hline & NRA V3 & NRA R5 \\
\hline TSW & $0,81^{* *}$ & $0,83^{* *}$ \\
PH & $0,62^{* *}$ & $0,64^{* *}$ \\
NPP & $0,60^{* *}$ & $0,70^{* *}$ \\
NSP & $0,39 *$ & $0,44^{* *}$ \\
\hline *Significant by the $t$ test at 1\% error probability; *Significant by the $t$ test at 5\% error probability; NS = Not significant by the t test; Thousand-seed weight (TSW); Plant height \\
$(\mathrm{PH})$; Number of pods per plant (NPP); Number of seeds per plant (NSP); Nitrate reductase enzyme activity obtained in the vegetative stage V3 (NRA V3) and Nitrate
\end{tabular}

(PH); Number of pods per plant (NPP); Number of seeds per plant (NSP); N
reductase enzyme activity obtained in the reproductive stage R5 (NRA R5).

It was evidenced that the addition of the inoculant with the Bradyrhizobium bacteria and of molybdenum improves the biological nitrogen fixation and the nitrate reductase enzyme activity, providing higher amounts of nitrogen for the plant and promoting a better development of the plants, resulting in the production of more vigorous seeds.

\section{Conclusions}

The inoculant contributed positively to the nitrate reductase enzyme activity; when associated to molybdenum, the enzymatic activity is higher.

The molybdenum doses without the presence of the inoculant provided a growing increase in the nitrate reductase enzyme activity.

The addition of the inoculant provides improvement of the agronomical traits and in the vigour expression of the produced seeds.

The application of molybdenum via seed treatment on sowing promotes increase in the shoot and root dry mass of plantlets originated from the produced seeds.

The molybdenum provides a linear increase in plant height and in the thousandseed weight.

The nitrate reductase enzyme activity presented a positive correlation with the vigour tests of the produced seeds and with the agronomical traits.

\section{References}

Araújo, G.A.A., Silva, A.A., Thomas, A., Rocha, P.R.R. 2008. Misturas de herbicidas com adubo molíbdico na cultura do Feijão. Planta Daninha 26: 237-247.
Bahry, C.A., Nardino, M., Venske, E., Fin, S.S., Zimmer, P.D., Souza, V.Q., Caron, B.O. 2014. Efeito do nitrogênio suplementar sobre os componentes de rendimento da soja em condição de estresse hídrico. Revista Ceres 61: 288-292.

Brasil. Ministério da Agricultura, Pecuária e Abastecimento. 2009. Regras para análise de sementes. Mapa/ACS, Brasília, Brasil, p.399.

Cassán, F., Perrig, D., Sgroy, V., Masciarelli, O., Penna, C., Luna, V. 2009. Azospirillum brasilense Az39 and Bradyrhizobium japonicum E109, inoculated singly or in combination, promote seed germination and early seedling growth in corn (Zea mays L.) and soybean (Glycine max L.) . Europian Journal of Soil Biology 45: 28-35.

Chaiklahan, R., Nattayaporn, C., Wipawan, S., Kalyanee, P., Boosya, B. 2010. Cultivation of Spirulina platensis using pig wastewater in a semicontinuous process. Journal of Microbiology and Biotechnology 20: 609-614.

Comissão De Química E Fertilidade Do Solo, CqfsRs/Sc. Manual de adubação e calagem para os estados do Rio Grande do Sul e Santa Catarina. 2004.

Donato, V.M.T.S., Andrade, A.G., Souza, E.S., França, J.G.E., Maciel, G.A. 2004. Atividade enzimática em variedades de cana-de-açúcar cultivadas in vitro sob diferentes níveis de nitrogênio. Pesquisa Agropecuária Brasileira 39: 1087-1093.

Farooq, M., Wahid, A., Kadambot, H., Siddique, M. 2012. Micronutrients application through seed treatments: a review. Journal of Soil Science and Plant Nutrition 12: 125-142.

Fernandez, E., Galvan, A. 2008. Nitrate assimilation in Chlamydomonas. Eukaryotic cell 7: 555-559.

Golo, A.L., Kappes, C., Carvalho, M.A.C., Yamashita, O.M. 2009. Qualidade das sementes de soja com a aplicação de diferentes doses de molibdênio e cobalto. Revista Brasileira de 
Sementes 31: 040-049.

Hageman, R.H., Reed, A.J. 1980. Nitrate reductase from higher plants. Methods Enzymol 69: 270-280.

Machado, A.A., Conceição, A.R. 2003. Sistema de análise estatística para Windows. WinStat. Versão 2.0. UFPel.

Marcos Filho, J. 2005. Fisiologia de sementes de plantas cultivadas. FEALQ, Piracicaba, Brasil, 495p.

Milani, G.L., Oliveira, J.A., Pereira, E.M., Carvalho, B.O., Oliveira, G.E., Costa, R.R. 2010. Aplicação foliar de molibdênio durante a maturação de sementes de soja. Ciência e Agrotecnologia 34: 810-816.

Milani, G.L., Oliveira, J.A., Silva, L.H.C., Pinho, E.V.R.V., Guimarães, R.M. 2008. Nodulação e desenvolvimento de plantas oriundas de sementes de soja com altos teores de molibdênio. Revista Brasileira de Sementes 30: 019-027.

Moraes, L.M.F., Lana, R.M.Q., Mendes, C., Mendes, E., Monteiro, A., Alves, J.F. 2008. Redistribuição de molibdênio aplicado via foliar em diferentes épocas na cultura da soja. Ciência e Agrotecnologia 32: 1496-1502.

Nakagawa, J. 1999. Testes de vigour baseados no crescimento de plântulas. In: Krzyzanowski, F.C. Vieira, R.D., França-Neto, J.B. (ed.) Vigour de sementes: conceitos e testes. ABRATES, Londrina, Brasil. p. 2-21

Oliveira, R.H., Souza, M.J.L., Moraes, O.M., Guimarães, B.V.C., Pereira Junior, H.A. 2010. Potencial fisiológico de sementes de mamona tratadas com micronutrientes. Acta Scientiarum Agronomy 32: 701- 707.

Possenti, J.C., Villela, F.A. 2010. Efeito do molibdênio aplicado via foliar e via sementes sobre o potencial fisiológico e produtividade de sementes de soja. Revista Brasileira de Sementes 32: 143-150.

Rampim, L., Costa, A.C.P.R., Nacke, H., Klein, J., Guimarães, V.F. 2012. Qualidade fisiológica de sementes de três cultivares de trigo submetidos à inoculação e diferentes tratamentos. Revista Brasileira de Sementes 34: 678 - 685.

Reis, A.R., Junior, E.F., Haga, K.I. 2007. Atividade da redutase do nitrato em folhas de cafeeiro em função da adubação nitrogenada. Acta Scientiarum Agronomy 29: 269-276.

Silveira, J.A.G., Figueiredo, M.V.B., Cavalcanti, F.R., Ferreira-Silva, S.L. 2011. Legume Nodule Oxidative Stress and N2 Fixation Efficiency. In: Microbial Ecology of Tropical Soils. New York: Nova Science Publishers Inc. 1: 9-78.
Toledo, M.Z., Garcia, R.A., Pereira, M.R.R., Boaro, C.S.F., Lima, G.P.P. 2010. Nodulação e atividade da nitrato redutase em função da aplicação de molibdênio em soja. Bioscience Jornal 26: 858864. 